\title{
KARAKTERISTIK, KESESUAIAN, DAN PENGELOLAAN LAHAN TAMBAK DI KOTA PEKALONGAN PROVINSI JAWA TENGAH
}

\author{
Rachmansyah, Akhmad Mustafa, dan Mudian Paena \\ Balai Riset Perikanan Budidaya Air Payau \\ Jl. Makmur Dg. Sitakka No. 129, Maros, Sulawesi Selatan 90511 \\ E-mail: rachman222000@yahoo.com
}

(Naskah diterima: 12 Agustus 2010; Disetujui publikasi: 1 Desember 2010)

\begin{abstract}
ABSTRAK
Kota Pekalongan memiliki lahan tambak yang produktivitas tambaknya masih tergolong relatif rendah. Oleh karena itu, dilakukan penelitian untuk mengetahui karakteristik lahan dalam upaya menentukan kesesuaian dan pengelolaan lahan untuk budidaya tambak demi peningkatan produktivitas tambak di Kota Pekalongan. Faktor yang dipertimbangkan dalam mengetahui karakteristik lahan adalah: tanah, topografi, hidrologi, vegetasi, dan iklim. Analisis spasial dalam Sistem Informasi Geografis digunakan dalam penentuan kesesuaian lahan untuk budidaya tambak. Pengelolaan lahan ditentukan berdasarkan karakteristik lahan yang disesuaikan dengan teknologi dan komoditas yang dapat diaplikasikan di tambak. Tanah tambak di Kota Pekalongan tergolong tanah aluvial non-sulfat masam yang tidak memiliki potensi kemasaman tanah yang tinggi dan sebagian kecil tanah sulfat masam. Sumber air laut untuk tambak tergolong agak keruh dan salinitas air tambak cukup bervariasi sebagai akibat adanya sumber air tawar yang berasal dari Sungai Pekalongan dan sodetan. Vegetasi bakau adalah jenis vegetasi yang dominan di kawasan tambak sebab adanya Program GERHAN (Gerakan Nasional Rehabilitasi Hutan dan Lahan) di Kota Pekalongan. Curah hujan di Kota Pekalongan sebesar $2.300 \mathrm{~mm} /$ tahun di mana curah hujan yang rendah dijumpai pada bulan Juli sampai Oktober. Di kawasan pesisir Kota Pekalongan dijumpai tambak, sawah, sawah terintrusi, dan pemukiman yang luasnya masing-masing 332,29; 372,53; 183,83; dan 61 9,73 ha. Dari luas tambak yang ada di Kota Pekalongan, yaitu 331,292 ha ternyata tidak ada tambak yang tergolong sangat sesuai (kelas S1), 191,856 ha tergolong cukup sesuai (kelas S2) dan 140,436 ha tergolong kurang sesuai (kelas S3). Pada areal yang mengandung unsur atau senyawa penyebab kemasaman yang tinggi disarankan untuk melakukan upaya perbaikan tanah terlebih dahulu berupa remediasi, pemberian pupuk yang mengandung nitrogen pada areal yang memiliki rasio C: $\mathrm{N}$ tanah yang tinggi serta pemberian pupuk kandang pada tanah yang mengandung liat lebih besar $60 \%$ dan bahan organik kurang dari $8 \%$.
\end{abstract}

KATA KUNCl: karakteristik, kesesuaian, pengelolaan, tambak, Kota Pekalongan

ABSTRACT: Characteristics, suitability, and management of land for brackishwater ponds in Pekalongan City, Central Java Province. By: Rachmansyah, Akhmad Mustafa, and Mudian Paena

Pekalongan City has brackishwater ponds with low productivity. Hence, a survey was conducted to know land characteristics as an effort to determine land suitability and land management to increase the productivity of brackishwater ponds in Pekalongan City, Central Java Province. Factors considered to determine the characteristics of 
land were soil, topography, hydrology, vegetation, and climate. Spatial analysis in Geographical Information System was used to determine land suitability for brackishwater ponds. Land management was determined based on the characteristics of land conditioned to the types of technology and commodity applied in the brackishwater ponds. Soil of brackishwater ponds in Pekalongan City was dominated by alluvial non-acid sulfate soil in large areas and acid sulfate soil in small areas. Source of sea water for brackishwater ponds has high turbidity and high variation of salinity due to presence of freshwater supply from Pekalongan River and man made canals. Mangrove vegetation is dominant in the coastal area of Pekalongan City, because the presence of GERHAN (National Action for Forest and Land Rehabilitation) Program. The average of rainfall in Pekalongan City is $2,230 \mathrm{~mm} /$ year, where low of rainfall occurrs in July until October. The result revealed that the coastal area of Pekalongan City had brackishwater ponds, paddy field, paddy field intruded saline water and settlement of $332.29 \mathrm{ha} ; 372.53 \mathrm{ha} ; 183.83 \mathrm{ha}$; and $619.73 \mathrm{ha}$, respectively. From the total brackishwater ponds in Pekalongan City i.e. 331.292 ha, there were no brackishwater ponds classified as highly suitable (S1 class), but it was found moderately suitable or S2 class (191.856 ha) and marginally suitable or S3 class $(140,436 \mathrm{ha})$. It is suggested to conduct improving soil quality first, including remediation of the areas that contain elements or compounds causing the high acidity of soil, fertilizing with fertilizer containing nitrogen in the areas that have high C: $N$ ratio and applying manure in the soils that contain clay more than $60 \%$ and organic matter less than $8 \%$.

\section{KEYWORDS: characteristic, suitability, management, brackishwater pond, Pekalongan City}

\section{PENDAHULUAN}

Kota Pekalongan Provinsi Jawa Tengah dengan luas 45,25 $\mathrm{km}^{2}$ terletak di dataran rendah pantai Utara Pulau Jawa, dengan ketinggian kurang lebih satu meter di atas permukaan laut dan posisi geografis antara: 6०50'42'"-655'44"' Lintang Selatan, 109³7'55"'-10942'19', Bujur Timur, serta berkoordinat fiktif 510,00-518,00 km membujur dan 517,75-526,75 km melintang. Batasbatas wilayah administratif sebagai berikut: sebelah utara: Laut Jawa; sebelah selatan: Kabupaten Pekalongan dan Kabupaten Batang; sebelah barat: Kabupaten Pekalongan; sebelah timur: Kabupaten Batang. Kota Pekalongan terbagi dalam 46 kelurahan, yang kesemuanya merupakan desa/kelurahan swasembada. Desa/Kelurahan tersebut tersebar ke dalam 4 wilayah kecamatan yaitu Kecamatan Pekalongan Barat, Pekalongan Timur, Pekalongan Selatan, dan Pekalongan Utara. Kota Pekalongan terkenal sebagai kota batik. Istilah Batik menjadi motto Kota Pekalongan yang merupakan akronim dari "Bersih Aman Tertib Indah dan Komunikatif". Selain itu juga terkenal sebagai kota perikanan, karena di sini terdapat Pelabuhan Perikanan Nusantara yang menjadi salah satu Pusat Pendaratan Ikan terbesar di Asia Tenggara.
Kementerian Kelautan dan Perikanan (KKP) telah memfokuskan untuk menggenjot produksi perikanan budidaya dan mengendalikan perikanan tangkap. Oleh karena potensi sumberdaya perikanan tangkap terbatas, maka peluang sekaligus tumpuan besar akan tertuju pada perikanan budidaya. Total target produksi perikanan budidaya Indonesia yang ingin dicapai pada tahun 2014 adalah sekitar 16,8 juta ton yang berarti peningkatan produksi sampai 353\%. Dari berbagai komoditas perikanan budidaya, KKP telah menentukan komoditas unggulan, di antaranya rumput laut, ikan bandeng, udang windu, dan udang vaname yang merupakan komoditas yang dapat dibudidayakan di tambak. KKP juga telah mencanangkan revitalisasi tambak yang akan dimulai di Pulau Jawa yang juga dimaksudkan agar target produksi perikanan budidaya dapat tercapai.

Semua jenis komoditas termasuk komoditas perikanan budidaya yang berbasis lahan untuk dapat tumbuh atau hidup dan berproduksi memerlukan persyaratan-persyaratan tertentu, yang dapat berbeda satu sama lain. Dalam kaitannya dengan sumberdaya alam, dikenal istilah lahan yang merupakan suatu lingkungan fisik yang terdiri atas tanah, topografi, hidrologi, vegetasi, dan iklim di mana pada 
batas-batas tertentu mempengaruhi kemampuan penggunaan lahan (FAO, 1976 dalam Rayes, 2007). Oleh karena itu, perbedaan kombinasi penyusun lingkungan fisik lahan tersebut akan memberikan karakteristik lahan yang berbeda dan pada akhirnya kesesuaian dan pengelolaan lahan yang berbeda pula.

Menurut Rossiter (1996), evaluasi kesesuaian lahan sangat penting dilakukan karena lahan memiliki sifat fisik, sosial, ekonomi, dan geografi yang bervariasi atau lahan diciptakan tidak sama. Evaluasi kesesuaian lahan dapat memprediksi keragaan lahan dalam hal keuntungan yang diharapkan dari penggunaan lahan dan kendala penggunaan lahan yang produktif serta degradasi lingkungan yang diperkirakan akan terjadi karena penggunaan lahan. Kesesuaian Iahan merupakan suatu kunci sukses dalam kegiatan akuakultur yang mempengaruhi kesuksesan dan keberlanjutannya serta dapat memecahkan konflik antara berbagai kegiatan dan membuat penggunaan lahan lebih rasional (Pérez et al., 2003; Hossain \& Das, 2010).

Pengelolaan lahan yang tepat dapat meningkatkan produktivitas lahan termasuk lahan budidaya tambak dengan penggunaan masukan yang seminimum mungkin dan tidak menyebabkan terjadinya degradasi lingkungan. Setiap jenis lahan memiliki karakteristik tersendiri sehingga pengelolaan lahannya juga bersifat khas terhadap penggunaan lahan tersebut (Mustafa \& Rachmansyah, 2008).

Sejak diberlakukan otonomi daerah, maka setiap kabupaten atau kota di Indonesia, termasuk Kota Pekalongan Provinsi Jawa Tengah, memiliki hak yang seluas-luasnya untuk mengeksploitasi dan mengekplorasi potensi sumberdaya yang ada, selain itu juga memiliki hak penuh untuk menentukan arah dan strategi pengembangan wilayahnya termasuk wilayah pesisir. Berbagai pendekatan dan konsep telah dilakukan oleh setiap kabupaten atau kota untuk mengembangkan wilayah pesisirnya, namun konflik sektoral dan kepentingan masih mewarnai pengelolaan wilayah pesisir pada umumnya di Indonesia. Untuk menjaga keselarasan dan koordinasi dengan pengembangan sektor lainnya, maka pengembangan sumberdaya perikanan termasuk perikanan budidaya perlu direncanakan dengan berbasis pada pengelolaan ruang. Oleh karena itu, dilakukan penelitian yang bertujuan untuk mengetahui karakteristik lahan sebagai upaya untuk menentukan kesesuaian dan pengelolaan lahan untuk budidaya tambak agar produktivitas tambak dapat meningkat dan berkelanjutan serta dapat menjadi acuan Pemerintah Kota Pekalongan secara khusus dan Pemerintah Provinsi Jawa Tengah secara umum dalam penentuan Rencana Tata Ruang Wilayah.

\section{BAHAN DAN METODE}

\section{Lokasi dan Waktu Penelitian}

Penelitian dilaksanakan di wilayah pesisir Kecamatan Pekalongan Utara yang merupakan satu-satunya kecamatan di Kota Pekalongan yang memiliki lahan tambak (Gambar 1). Penelitian yang dilaksanakan pada bulan Oktober 2009 ini diawali berupa diskusi dengan staf Dinas Pertanian, Peternakan dan Kelautan Kota Pekalongan untuk mendapatkan informasi umum mengenai lahan budidaya tambak di Kota Pekalongan.

\section{Pengumpulan Data}

\section{Data primer}

Data primer yang dikumpulkan meliputi data biofisik yaitu: tanah, topografi, hidrologi, dan vegetasi. Peubah kualitas tanah yang diukur langsung di lapangan adalah $\mathrm{pH}_{\mathrm{F}}(\mathrm{pH}$ tanah yang diukur di lapangan) dengan $\mathrm{pH}$-meter dan $\mathrm{pH}_{\text {FOX }}(\mathrm{pH}$ tanah yang diukur di lapangan setelah dioksidasi dengan hidrogen peroksida $\left(\mathrm{H}_{2} \mathrm{O}_{2}\right) 30 \%$ ) dengan pH-meter (Ahern \& Rayment, 1998). Contoh tanah diambil pada dua kedalaman tanah yaitu 0-0,2 dan 0,5-0,7 m dari permukaan tanah. Sisa tumbuhan segar, kerikil, cangkang, dan kotoran lainnya dibuang dan bongkahan besar dikecilkan dengan tangan. Untuk analisis peubah kualitas tanah lainnya, maka contoh tanah dimasukkan secepatnya dalam kantong plastik dan selanjutnya dimasukkan lagi dalam cool box yang diberi es, karena adanya contoh tanah yang tergolong tanah sulfat masam. Contoh tanah diovenkan pada suhu $80^{\circ} \mathrm{C}-85^{\circ} \mathrm{C}$ selama 48 jam (Ahern \& Blunden, 1998) untuk tanah sulfat masam, sedangkan contoh tanah lainnya dikeringanginkan. Setelah kering, contoh tanah dihaluskan dengan cara ditumbuk pada lumpang porselin dan diayak dengan ayakan ukuran lubang $2 \mathrm{~mm}$ dan selanjutnya dianalisis di Laboratorium Tanah 


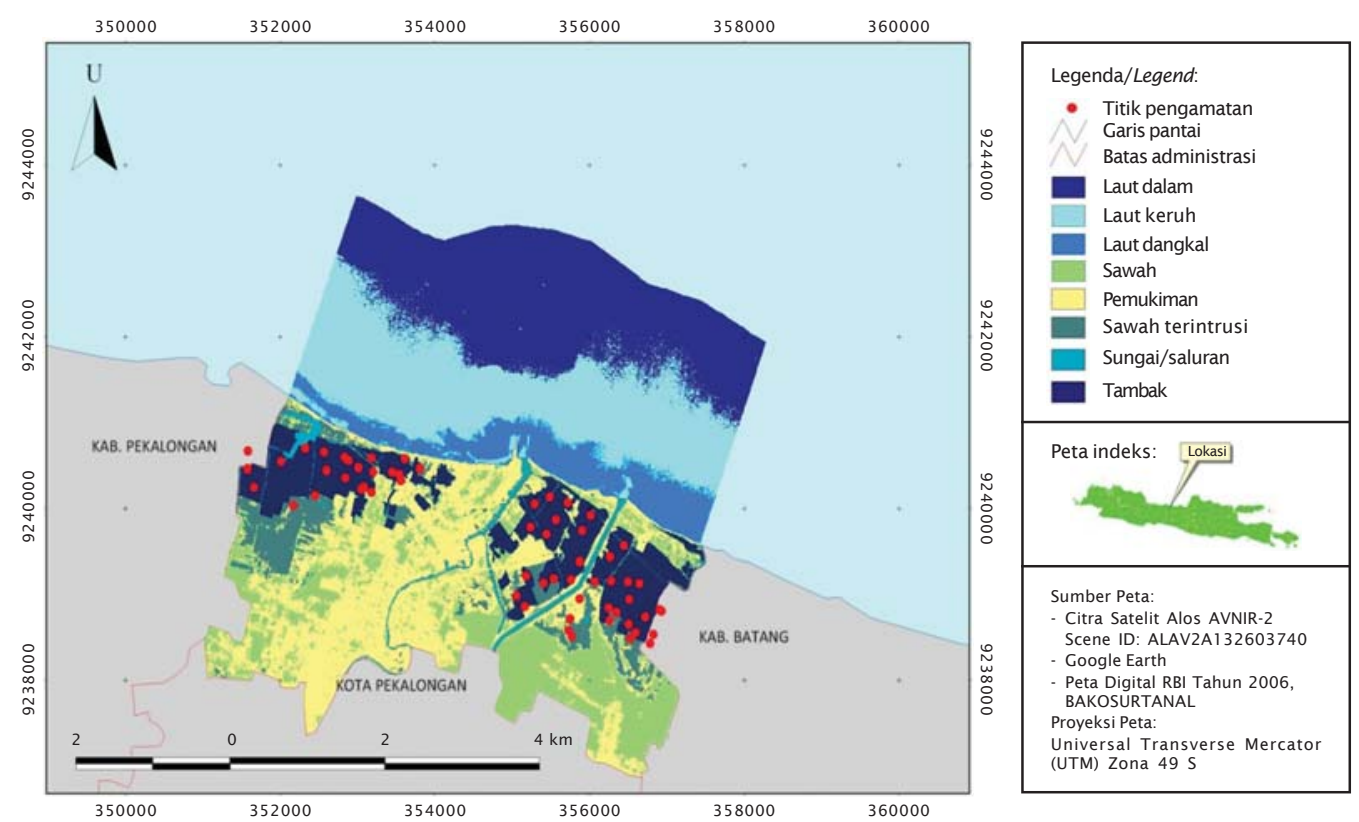

Gambar 1. Titik pengukuran dan pengambilan contoh tanah di kawasan pesisir Kecamatan Pekalongan Utara, Kota Pekalongan Provinsi Jawa Tengah

Figure 1. Measurement and collection of soils sample points in the coastal area of North Pekalongan Sub-district, Pekalongan City Central Java Province

Balai Riset Perikanan Budidaya Air Payau (BRPBAP) di Maros. Kualitas tanah yang dianalisis di laboratorium meliputi $S_{p}$ (sulfur peroksida), $\mathrm{S}_{\mathrm{KCI}}$ (sulfur yang diekstrak dengan $\mathrm{KCl}), \mathrm{S}_{\mathrm{POS}}\left(\mathrm{S}_{\mathrm{P}}-\mathrm{S}_{\mathrm{KCl}}\right)$, TPA (Titratable Peroxide Acidity atau sebelumnya dikenal dengan Total Potential Acidity), TAA (Titratable Actual Acidity atau sebelumnya dikenal dengan Total Actual Acidity), TSA (Titratable Sulfidic Acidity atau sebelumnya dikenal dengan Total Sulfidic Acidity) (TPA-TAA), pirit, karbon organik dengan metode Walkley dan Black, $\mathrm{N}$-total dengan metode Kjedhal, $\mathrm{PO}_{4}$ dengan metode Bray 1 atau Olsen, Fe dengan spektrofotometer, Al dengan spektrofotometer dan tekstur dengan metode hidrometer (Melville, 1993; Ahern et al., 1998a, 1998b; Ahern \& McElnea, 2004; McElnea \& Ahern, 2004a, 2004b, 2004c, 2004d; Sulaeman et al., 2005).

Topografi diketahui melalui pengamatan di lapangan dan hasil pengukuran dengan menggunakan Theodolite. Data hidrologi diketahui dari pasang surut dan kualitas air. Data pasang surut diperoleh dari Jawatan Hidro-Oseanografis (2009) untuk lokasi yang terdekat dari Kota Pekalongan yaitu Kota Semarang. Pengukuran dan pengambilan contoh air dilakukan di sungai, sodetan, laut, saluran, dan tambak. Pengukuran dan pengambilan contoh air di tambak mengikuti titik pengambilan contoh tanah. Peubah kualitas air yang diukur langsung di lapangan adalah suhu, salinitas, oksigen terlarut dan $\mathrm{pH}$ dengan menggunakan Hydrolab ${ }^{\circledR}$ Minisonde. Contoh air untuk analisis di laboratorium diambil dengan menggunakan Kmerer Water Sampler dan dipreservasi mengikuti petunjuk APHA (2005). Peubah kualitas air yang dianalisis di Laboratorium Air BRPBAP di Maros meliputi: $\mathrm{NH}_{3}, \mathrm{NO}_{3}, \mathrm{NO}_{2}$, dan Fe berdasarkan petunjuk Menon (1973), Parsons et al. (1989), dan APHA (2005).

Spesies vegetasi mangrove diketahui dengan mencatat setiap jenis vegetasi mangrove yang ditemui. Identifikasi dan klasifikasi vegetasi mangrove ditentukan berdasarkan petunjuk Blasco (1984) dan Cintrõn \& Novelli (1984). Seluruh titik-titik pengamatan dan pengambilan contoh ditentukan titik koordinatnya dengan menggunakan Global Positioning System (GPS). 


\section{Data sekunder}

Data sekunder dikumpulkan melalui penelusuran berbagai laporan, pustaka, dan hasil penelitian dari berbagai instansi terkait. Peta yang dikumpulkan antara lain peta Rupabumi Indonesia skala 1:50.000 dengan nomor indeks 1409-1 12 (Pekalongan) dan peta Administrasi Kota Pekalongan.

\section{Analisis Data}

Statistik deskriptif digunakan untuk dapat menggambarkan data yang ada secara umum. Peta penutup/penggunaan lahan yang digunakan berasal dari hasil klasifikasi Citra ALOS (Advanced Land Observing Satellite) AVNIR-2 (The Advanced Visible and Near Infrared Radiometer type 2) akuisisi 21 Juli 2008 dengan Program Er Mapper 7.1 yang diintegrasikan dengan peta dasar dari peta Rupabumi Indonesia.

Informasi spasial lain yang diperoleh dari data primer dan sekunder juga diintegrasikan dengan peta penutup/penggunaan lahan. Data primer, sekunder, dan peta penutup/ penggunaan lahan yang sudah dikumpulkan, selanjutnya dilakukan pengolahan data dengan menggunakan analisis spasial dalam Sistem Informasi Geografis (SIG). Penilaian terhadap kesesuaian lahan budidaya tambak dilakukan dengan overlay (menumpangsusunkan) peta-peta tematik yang telah dibuat dengan metode pembobotan pada software ArcGIS 9.3 dengan faktor pembobot yang telah disusun. Kriteria yang digunakan dalam penentuan kesesuaian lahan untuk budidaya tambak mengacu pada kriteria yang ada (Mustafa et al., 2007).

Asumsi yang diterapkan dalam evaluasi kesesuaian lahan tambak disesuaikan pada pengelolaan yang rendah atau sederhana sampai sedang. Infrastruktur, aksesibilitas, dan pemasaran hasil produksi tidak dipertimbangkan dalam evaluasi kesesuaian lahan ini. Hasil proses penilaian kesesuaian lahan ditampilkan dalam bentuk sistem klasifikasi kesesuaian lahan aktual. Sistem klasfikasi kesesuaian lahan ditentukan sampai tingkat kategori Kelas. Pengelolaan lahan yang direkomendasikan didasarkan pada karakteristik lahan dan disesuaikan dengan tingkat teknologi dan komoditas yang diaplikasikan di tambak.

\section{HASIL DAN BAHASAN}

\section{Kondisi Umum}

Secara administratif, Kota Pekalongan terdiri atas 4 kecamatan yakni Kecamatan Pekalongan Barat, Pekalongan Selatan, Pekalongan Timur, dan Pekalongan Utara. Karena tambak hanya terkonsentrasi di wilayah Kecamatan Pekalongan Utara, karena wilayah ini terletak di wilayah pesisir pantai. Kecamatan Pekalongan Utara terdiri atas 9 kelurahan yaitu Kelurahan Panjang Wetan, Kandang Panjang, Kraton Lor, Dukuh, Bandengan, Pabean, Krapyak Lor, Krapyak Kidul, dan Degayu. Dari 9 kelurahan tersebut terdapat 5 kelurahan yang berhubungan dengan wilayah perairan laut yakni Kelurahan Bandengan, Kandang Panjang, Panjang Wetan, Krapyak Lor, dan Degayu. Lima kelurahan inilah yang menjadi lokasi penelitian.

Penggunaan lahan pantai dari masingmasing kelurahan tersebut cukup bervariasi (Gambar 2). Di Kelurahan Bandengan, Iahan pantai sebagian besar digunakan untuk pertanian dan pertambakan. Penggunaan lahan lainnya adalah untuk pemukiman penduduk. Di Kelurahan Kandang Panjang, didapatkan penggunaan lahan untuk pemukiman penduduk, sawah dan ladang serta tambak. Di kelurahan ini relatif belum banyak pemukiman yang mendekat pantai seperti di Kelurahan Panjang Wetan.

Kelurahan Panjang Wetan berjarak sekitar $1 \mathrm{~km}$ dari pusat Pemerintahan Kecamatan Pekalongan Utara. Penggunaan Iahan pantai Kelurahan Panjang Wetan didominasi oleh pemukiman penduduk yang sangat padat. Selain itu di kelurahan ini juga terdapat PPNP (Pelabuhan Perikanan Nusantara Pekalongan) sebagai tempat pendaratan ikan, kantor-kantor instansi pemerintah dan swasta, kawasan industri pengolahan ikan dan bengkel-bengkel kapal perikanan, wisata bahari dan sebagainya. Kawasan pertambakan/pertanian hanya menempati sebagian kecil lahan pantai dan tanah rawa yang belum dikelola. Garis pantainya telah dilindungi oleh bangunan penahan gelombang sepanjang kurang lebih $2 \mathrm{~km}$.

Di Kelurahan Krapyak Lor terdapat lahan pantai yang digunakan untuk tempat rekreasi seluas 6,49 ha. Lahan pantai lainnya digunakan 


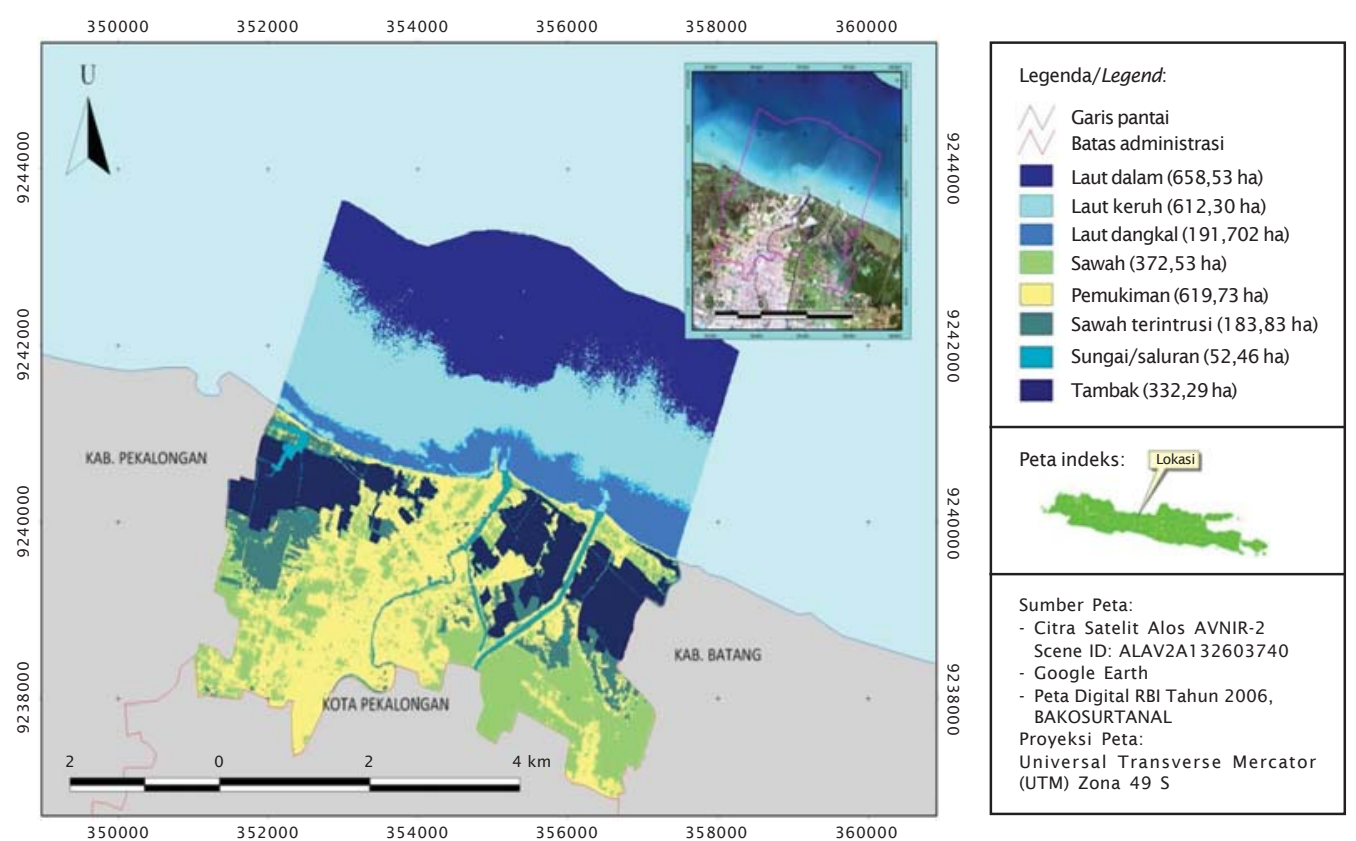

Gambar 2. Peta penutup/penggunaan lahan di Kecamatan Pekalongan Utara, Kota Pekalongan, Jawa Tengah

Figure 2. Map of land cover/utilisation in North Pekalongan Sub-district, Pekalongan City, Central Java Province

untuk pemukiman, pertanian dan tambak. Di Kelurahan Degayu ditempatkan TPA (Tempat Pembuangan Akhir) sampah kota oleh Pemerintah Kota Pekalongan seluas kurang lebih 5 ha. Sebagian besar lahan pantainya digunakan untuk persawahan dan tambak, sedangkan yang digunakan untuk pemukiman relatif belum begitu padat.

Peta penutup/penggunaan lahan Kota Pekalongan dapat dilihat pada Gambar 2. Di kawasan pesisir Kota Pekalongan dijumpai tambak, sawah, sawah terintrusi dan pemukiman yang luasnya masing-masing 332,29 ; 372,53 ; 183,83; dan 619,73 ha. Sawah terintrusi dijumpai pada daerah yang berdekatan dengan tambak dan menjadi sawah yang tidak produktif lagi.

\section{Karakteristik Lahan}

Telah disebutkan sebelumnya bahwa lahan adalah suatu lingkungan fisik yang terdiri atas tanah, topografi, hidrologi, vegetasi, dan iklim. Dengan demikian, setiap bagian dari lahan tersebut dibahas pada bagian berikut.

\section{Tanah}

Jenis tanah di Kota Pekalongan adalah tanah aluvial non-sulfat masam dan sebagian kecil tanah sulfat masam dengan warna agak kelabu. Kualitas tanah tambak di Kota Pekalongan dapat dilihat pada Tabel 1 dan 2.

Ciri tanah aluvial non-sulfat masam jelas terlihat pada Tabel 1 di mana $\mathrm{pH}_{\mathrm{F}}-\mathrm{pH}_{\text {Fox }}$ tidak terlalu besar. Hal yang sama juga dijumpai pada kedalaman 0,5-0,7 m (Tabel 2). $\mathrm{pH}_{\mathrm{F}}-\mathrm{pH}_{\mathrm{FOX}}$ dapat digunakan untuk menentukan potensi kemasaman yang ada pada tanah. Pada tanah sulfat masam, $\mathrm{pH}_{\mathrm{F}}-\mathrm{pH}_{\mathrm{FOX}}$ dapat mencapai $>5$.

Nilai $S_{\text {POS }}$ tanah telah digunakan oleh Ahern et al. (1998b) untuk menentukan kebutuhan kapur bagi tanah sulfat masam. Dari data yang ada (Tabel 1 dan 2) menunjukkan bahwa kandungan $\mathrm{S}_{\text {POS }}$ tanah tergolong rendah yang berarti membutuhkan kapur yang rendah pula. Seperti telah disebutkan sebelumnya, bahwa tanah tambak di Kota Pekalongan secara umum tergolong tanah aluvial non-sulfat masam, walaupun ada daerah tertentu yang dijumpai memiliki kandungan $S_{\text {pos }}$ tanah yang agak 
Tabel 1. Kualitas tanah tambak pada kedalaman 0-0,2 m di Kota Pekalongan, Provinsi Jawa Tengah

Table 1. Soil quality of bracksihwater ponds at 0-0.2 $\mathrm{m}$ depth in Pekalongan City, Central Java Province

\begin{tabular}{|c|c|c|c|c|}
\hline $\begin{array}{l}\text { Peubah } \\
\text { Variable }\end{array}$ & Minimum & $\begin{array}{l}\text { Maksimum } \\
\text { Maximum }\end{array}$ & $\begin{array}{l}\text { Rata-rata } \\
\text { Average }\end{array}$ & $\begin{array}{c}\text { Standar deviasi } \\
\text { Standard deviation }\end{array}$ \\
\hline $\mathrm{pH}_{\mathrm{F}}$ & 3.14 & 7.45 & 6.691 & 0.6296 \\
\hline $\mathrm{pH}_{\mathrm{FOX}}$ & 1.16 & 7.09 & 3.377 & 1.6385 \\
\hline $\mathrm{pH}_{\mathrm{F}}-\mathrm{pH}_{\mathrm{FOX}}$ & 0.61 & 5.74 & 3.314 & 1.8139 \\
\hline $\mathrm{S}_{\mathrm{KCl}}(\%)$ & 0.21 & 1.39 & 0.705 & 0.2896 \\
\hline$S_{P}(\%)$ & 0.14 & 27.30 & 7.487 & 9.5937 \\
\hline $\mathrm{S}_{\mathrm{POS}}(\%)$ & 0.69 & 26.66 & 6.782 & 9.5035 \\
\hline $\begin{array}{l}\text { TPA }\left(\mathrm{mol} \mathrm{H}^{+} / \text {ton }\right) / \\
\left.\text { (mole } \mathrm{H}^{+} / \text {ton }\right)\end{array}$ & 0.00 & 452.00 & 75.604 & 110.9251 \\
\hline $\begin{array}{l}\mathrm{TAA}\left(\mathrm{mol} \mathrm{H}^{+} / \text {ton }\right) / \\
\left(\text { mole } \mathrm{H}^{+} / \text {ton }\right)\end{array}$ & 0 & 0 & 0 & 0 \\
\hline $\begin{array}{l}\mathrm{TSA}\left(\mathrm{mol} \mathrm{H}^{+} / \text {ton }\right) / \\
\left.\text { (mole } \mathrm{H}^{+} / \text {ton }\right)\end{array}$ & 0.00 & 452 & 75.604 & 110.9251 \\
\hline $\begin{array}{l}\text { Bahan organik/ } \\
\text { Organic matter (\%) }\end{array}$ & 0.14 & 10.26 & 3.546 & 2.2759 \\
\hline Pirit (Pyrite) (\%) & 0.00 & 2.02 & 0.338 & 0.4952 \\
\hline $\mathrm{Fe}(\mathrm{mg} / \mathrm{L})$ & 9.50 & 4868.50 & 1422.472 & 1878.5631 \\
\hline $\mathrm{Al}(\mathrm{mg} / \mathrm{L})$ & $<0.001$ & 785.500 & 295.1714 & 212.76090 \\
\hline $\mathrm{PO}_{4}(\mathrm{mg} / \mathrm{L})$ & $<0.001$ & 148.486 & 42.5846 & 34.28708 \\
\hline N-total (Total-N) (\%) & 0.005 & 0.054 & 0.0263 & 0.01135 \\
\hline Rasio C:N (C:N ratio) & 3.1 & 286.1 & 78.33 & 47.452 \\
\hline Liat (Clay) (\%) & 32 & 86 & 69.1 & 11.54 \\
\hline Pasir (Sand) (\%) & 6 & 28 & 14.7 & 5.44 \\
\hline Debu (Silt ) (\%) & 0 & 46 & 16.2 & 9.20 \\
\hline
\end{tabular}

tinggi yaitu di Kelurahan Krapyak Lor. Hal ini juga diperlihatkan dengan tingginya kandungan unsur atau senyawa penyebab kemasaman seperti pirit, besi, aluminium, dan bahan organik di kelurahan tersebut.

Dijumpai nilai $\mathrm{S}_{\text {pos }}$ tanah yang lebih tinggi pada tanah sawah terintrusi daripada tanah tambak, terutama pada kedalaman 0-0,2 m yang diikuti juga dengan tingginya unsur atau senyawa penyebab kemasaman, terutama kandungan besi dan aluminium. Proses pencucian alami yang berlangsung lama dengan frekuensi pencucian yang lebih tinggi akibat pergantian air pada tambak, diduga merupakan salah satu penyebab lebih rendahnya kandungan unsur atau senyawa tersebut pada tanah tambak daripada tanah sawah terintrusi.

Seperti telah disebutkan sebelumnya, bahwa kandungan bahan organik tanah yang tinggi dijumpai di Kelurahan Krapyak Lor. Hal yang sama juga dijumpai di Kelurahan Bandengan dalam luasan yang lebih sempit. Namun demikian, tanah di kedua kelurahan tersebut belum digolongkan sebagai tanah gambut sebab kandungan bahan organiknya masih lebih rendah dari 20\%. Tanah gambut adalah tanah yang mengandung bahan organik lebih dari $20 \%$ (bila tanah tidak mengandung liat) atau lebih dari 30\% (bila tanah mengandung liat lebih besar dari atau sama dengan 60\%) (Soil Survey Staff, 2001). 
Tabel 2. Kualitas tanah tambak pada kedalaman 0,5-0,7 m di Kota Pekalongan Provinsi Jawa Tengah

Table 2. Soil quality of brackishwater ponds at 0.5-0.7 m depth in Pekalongan City Central Java Province

\begin{tabular}{|c|c|c|c|c|}
\hline $\begin{array}{l}\text { Peubah } \\
\text { Variable }\end{array}$ & Minimum & $\begin{array}{l}\text { Maksimum } \\
\text { Maximum }\end{array}$ & $\begin{array}{l}\text { Rata-rata } \\
\text { Average }\end{array}$ & $\begin{array}{c}\text { Standar deviasi } \\
\text { Standard deviation }\end{array}$ \\
\hline $\mathrm{pH}_{\mathrm{F}}$ & 4.92 & 8.49 & 6.431 & 0.5957 \\
\hline $\mathrm{pH}_{\mathrm{FOX}}$ & 1.04 & 7.53 & 3.101 & 2.0593 \\
\hline $\mathrm{pH}_{\mathrm{F}}-\mathrm{pH}_{\mathrm{FOX}}$ & 1.11 & 7.45 & 3.331 & 2.2746 \\
\hline $\mathrm{S}_{\mathrm{KCl}}(\%)$ & 0.14 & 2.03 & 0.659 & 0.3657 \\
\hline$S_{p}(\%)$ & 0.16 & 27.24 & 9.260 & 10.0621 \\
\hline $\mathrm{S}_{\mathrm{POS}}(\%)$ & 1.45 & 26.13 & 8.601 & 9.9856 \\
\hline $\begin{array}{l}\mathrm{TPA}\left(\mathrm{mol} \mathrm{H}^{+} / \text {ton }\right) / \\
\left(\text { mole } \mathrm{H}^{+} / \text {ton }\right)\end{array}$ & 0.00 & 930.00 & 177.455 & 240.6631 \\
\hline $\begin{array}{l}\text { TAA }\left(\mathrm{mol} \mathrm{H}^{+} / \text {ton }\right) / \\
\left.\text { (mole } \mathrm{H}^{+} / \text {ton }\right)\end{array}$ & 0.00 & 6.50 & 0.292 & 1.1327 \\
\hline $\begin{array}{l}\mathrm{TSA}\left(\mathrm{mol} \mathrm{H}^{+} / \text {ton }\right) / \\
\left.\text { (mole } \mathrm{H}^{+} / \text {ton }\right)\end{array}$ & 6.5 & 930.00 & 177.162 & 240.7519 \\
\hline $\begin{array}{l}\text { Bahan organik/ } \\
\text { Organic matter (\%) }\end{array}$ & 0.27 & 34.45 & 4.430 & 5.2410 \\
\hline Pirit (Pyrite) (\%) & 0.03 & 4.15 & 0.791 & 1.0748 \\
\hline $\mathrm{Fe}(\mathrm{mg} / \mathrm{L})$ & 9.5 & 4917.00 & 1977.962 & 2138.6228 \\
\hline $\mathrm{Al}(\mathrm{mg} / \mathrm{L})$ & $<0.001$ & 1334.000 & 466.1750 & 316.79753 \\
\hline $\mathrm{PO}_{4}(\mathrm{mg} / \mathrm{L})$ & $<0.001$ & 294.740 & 42.1394 & 51.01205 \\
\hline N-total (Total-N) (\%) & 0.003 & 0.060 & 0.0205 & 0.01316 \\
\hline Rasio C:N (C:N ratio) & 8.7 & 480.9 & 120.30 & 86.448 \\
\hline Liat (Clay) (\%) & 32 & 86 & 72.6 & 8.59 \\
\hline Pasir (Sand) (\%) & 4 & 30 & 13.7 & 5.76 \\
\hline Debu (Silt ) (\%) & 0 & 46 & 13.7 & 6.16 \\
\hline
\end{tabular}

Walaupun kandungan bahan organik tanah secara umum relatif rendah, tetapi kandungan $\mathrm{N}$-total yang sangat rendah berdampak pada sangat tingginya rasio $\mathrm{C}: \mathrm{N}$ tanah tambak di Kota Pekalongan (Tabel 1 dan 2). Rasio C:N yang ideal untuk tambak adalah 8:1 sampai 12:1 (Boyd, 2008). Pada tanah dengan rasio C:N tinggi, maka terjadi immobilisasi $\mathrm{N}$ oleh mikrobiologi untuk memenuhi kebutuhan metabolismenya.

Tekstur tanah tambak sangat berpengaruh terhadap porositas dan pertumbuhan kelekap yang dapat menjadi salah satu sumber makanan bagi ikan dan udang. Tambak dengan tanah bertekstur kasar seperti pasir berlempung dan pasir memiliki tingkat porositas yang tinggi, sebagai akibatnya tambak tidak bisa menahan air. Tanah tambak sering dijumpai bertekstur halus dengan kandungan liat minimum 20-30\% untuk menahan peresapan ke samping (Boyd, 1995). Tekstur tanah yang baik untuk tambak adalah: liat, lempung berliat, lempung liat berdebu, lempung berdebu, lempung dan lempung liat berpasir (Ilyas et al., 1987). Secara umum, tanah tambak di Kota Pekalongan tergolong tekstur liat berat atau memiliki kandungan liat yang sangat tinggi. Dikatakan oleh Boyd (1995) bahwa suatu material tanah yang merupakan campuran dari partikel yang berbeda ukuran dan mengandung minimum $30 \%$ liat adalah ideal untuk konstruksi tambak. Kandungan liat tanah ini mendukung usaha budidaya tambak yang masih memerlukan 
makanan alami seperti kelekap sebagai sumber utama makanan bagi organisme yang dibudidayakan di tambak. Dalam hal ini, teknologi tradisional dan tradisional plus adalah pilihan yang dapat dilakukan di tambak.

\section{Topografi}

Ketinggian lahan tambak di Kecamatan Pekalongan Utara berkisar antara 1 sampai $2 \mathrm{~m}$ di atas permukaan laut. Ketinggian lahan tambak 1-3 m di atas permukaan laut dijumpai di Kelurahan Bandengan; ketinggian 1-2 m di atas permukaan laut dijumpai di Kelurahan Panjang Wetan, sedangkan ketinggian sekitar 1 m dijumpai di Kelurahan Kandang Panjang, Krapyak Lor, dan Degayu. Vegetasi mangrove yang tumbuh di tambak di Kecamatan Pekalongan Utara juga mengindikasikan bahwa ketinggian tambak dapat dijangkau oleh air pasang. Hal ini menunjukkan juga secara umum kawasan mangrove berada pada topografi yang relatif datar dan elevasi yang dapat dijangkau oleh pasang surut agar mangrove dapat hidup dan berkembang. Dengan demikian, topografi kawasan tambak di Kota Pekalongan tergolong rendah dan datar. Chanratchakool et al. (1995) menyarankan lahan yang baik untuk budidaya tambak adalah relatif datar.

\section{Hidrologi}

Kota Pekalongan memiliki garis pantai kurang lebih sepanjang $6 \mathrm{~km}$ membentang dari Barat ke Timur berhadapan langsung dengan Laut Jawa. Secara morfologis pantainya berbentuk landai yang didominasi oleh hamparan pasir, tidak berbatu, perairannya bersifat terbuka, bukan merupakan teluk, dan ombak pantainya relatif berkekuatan rendah.
Warna perairan pantai keruh kecoklatan dan pada jarak kurang lebih 1 mil warna terlihat hijau kebiruan. Kedalaman perairan pantai antara 0,5-25 m dengan kecepatan arus yang cukup deras.

Wilayah pesisir Kota Pekalongan memiliki dua muara sungai besar yakni muara Sungai Pekalongan yang terletak di perbatasan pantai Kelurahan Panjang Wetan dan Krapyak Lor serta muara sungai sodetan (muara sungai baru) di pantai Kelurahan Degayu. Keberadaan sungai tersebut dapat memberikan variasi salinitas air tambak yang cukup besar seperti terlihat pada Tabel 3. Salinitas air tambak berkisar dari 9 sampai 70 ppt dengan rata-rata 38,6 ppt. Udang windu (Penaeus monodon), udang vaname (Litopenaeus vannamei), ikan bandeng (Chanos chanos) dan rumput laut (Gracilaria verrucosa) merupakan organisme eurihalin, namun karena dibudidayakan untuk tujuan komersial, kisaran salinitas yang optimum perlu dipertahankan. Udang windu mampu menyesuaikan diri terhadap salinitas 3-45 ppt (Tseng, 1987 dalam Poernomo, 1988), namun untuk pertumbuhan optimum diperlukan salinitas 15-25 ppt (Poernomo, 1988). Udang vaname umumnya tumbuh optimum pada salinitas 15-20 ppt (Bray et al., 1994). Ikan bandeng dapat tumbuh dengan baik pada salinitas 18-30 ppt (Ismail et al., 1993). Salinitas optimum untuk rumput laut adalah 15 sampai 25 ppt (Anonymous, 1991). Dari rata-rata salinitas di pertambakan Kota Pekalongan, tergolong berada pada salinitas yang agak tinggi bagi berbagai komoditas air payau. Hal ini sebagai akibat dari pengukuran yang dilakukan pada saat musim kemarau yang dapat menyebabkan tingginya laju penguapan yang dapat mempertinggi salinitas.

Tabel 3. Kualitas air tambak di Kota Pekalongan Provinsi Jawa Tengah yang diukur di lapangan

Table 3. Water quality of brackishwater ponds in Pekalongan City Central Java Province measured in situ

\begin{tabular}{lcccc}
\hline $\begin{array}{c}\text { Peubah } \\
\text { Variable }\end{array}$ & Minimum & $\begin{array}{c}\text { Maksimum } \\
\text { Maximum }\end{array}$ & $\begin{array}{c}\text { Rata-rata } \\
\text { Average }\end{array}$ & $\begin{array}{c}\text { Standardeviasi } \\
\text { Standard deviation }\end{array}$ \\
\hline Salinitas (Salinity) $(\mathrm{ppt})$ & 9.14 & 70.02 & 38.64 & 8.120 \\
Suhu (Temperature) $\left({ }^{\circ} \mathrm{C}\right)$ & 29.50 & 34.81 & 32.04 & 1.467 \\
$\mathrm{pH}$ & 7.34 & 8.96 & 8.47 & 0.336 \\
Oksigen terlarut & 2.40 & 7.91 & 5.74 & 1.198 \\
Dissolved oxygen $(\mathrm{mg} / \mathrm{L})$ & & & & \\
\hline
\end{tabular}


Suhu air di pertambakan Kota Pekalongan berkisar antara $29,5^{\circ} \mathrm{C}$ sampai $34,8^{\circ} \mathrm{C}$ dengan rata-rata $32,04^{\circ} \mathrm{C}$ (Tabel 5). Suhu air yang tinggi terukur pada tambak yang airnya sangat dangkal (kurang dari $10 \mathrm{~cm}$ ). Suhu air yang layak untuk budidaya udang windu berkisar antara $26^{\circ} \mathrm{C}$ dan $32^{\circ} \mathrm{C}$ (Poernomo, 1988) dan optimumnya antara $29^{\circ} \mathrm{C}$ dan $30^{\circ} \mathrm{C}$ (Poernomo, 1988). Suhu air $25^{\circ} \mathrm{C}-30^{\circ} \mathrm{C}$ adalah suhu yang baik untuk budidaya rumput laut (HurtadoPonce \& Umezaki, 1987). Pada suhu $25^{\circ} \mathrm{C}$ $32^{\circ} \mathrm{C}$ pertumbuhan ikan bandeng tergolong baik (Ismail et al., 1993). Suhu optimum untuk pertumbuhan udang vaname adalah $28^{\circ} \mathrm{C}-30^{\circ} \mathrm{C}$ (Ponce-Palatox et al., 1997).

Batas toleransi organisme akuatik terhadap $\mathrm{pH}$ bervariasi dan dipengaruhi oleh banyak faktor, antara lain: suhu oksigen terlarut, alkalinitas dan adanya anion dan kation serta jenis dan stadium organisme. Kisaran $\mathrm{pH}$ yang baik untuk udang windu adalah 7,5-8,7 dengan optimum 8,0-8,5 (Poernomo, 1988). Menurut Swingle (1968) pada umumnya $\mathrm{pH}$ air yang baik bagi organisme akuatik adalah 6,5-9,0; pada pH 9,5-11,0 dan 4,0-6,0 mengakibatkan produksi rendah dan jika lebih rendah dari 4,0 atau lebih tinggi 11,0 akan meracuni ikan. Dari Tabel 3 menunjukkan bahwa $\mathrm{pH}$ air tambak di Kota Pekalongan tergolong sesuai untuk budidaya perikanan air payau. Hal ini didukung dengan tanah yang tergolong tanah aluvial non-sulfat masam sehingga $\mathrm{pH}$ air tergolong netral.

Oksigen terlarut sangat esensial bagi pernapasan dan merupakan salah satu komponen utama dalam metabolisme akuatik. Kebutuhan organisme akan oksigen terlarut sangat bervariasi bergantung kepada jenis, stadium dan aktivitasnya. Oksigen terlarut air tambak di Kota Pekalongan berkisar 2,40 sampai 7,91 mg/L dengan rata-rata $5,74 \mathrm{mg} / \mathrm{L}$. Dalam hal ini, oksigen terlarut air tambak di Kota Pekalongan tergolong sesuai untuk budidaya tambak. Oleh karena budidaya yang diaplikasikan oleh pembudidaya tambak di Kota Pekalongan tergolong teknologi tradisional, sehingga masalah kandungan oksigen terlarut yang rendah belum menjadi masalah. Pada konsentrasi oksigen terlarut antara 1,5 dan 3,5 $\mathrm{mg} / \mathrm{L}$ dapat menyebabkan pertumbuhan serta konsumsi pakan dan efisiensi pakan pada udang windu menjadi rendah (Tsai, 1989). Batas oksigen terlarut untuk udang windu adalah 3-10 mg/L and optimum 4-7 mg/L (Poernomo, 1988). Dengan konsentrasi oksigen terlarut 1-5 mg/L dalam waktu yang sangat lama menyebabkan pertumbuhan udang windu menjadi lambat, konsentrasi oksigen terlarut $5 \mathrm{mg} / \mathrm{L}$ sampai jenuh adalah kondisi terbaik untuk pertumbuhan udang windu (Boyd, 1995).

Kualitas air di kawasan pertambakan Kota Pekalongan yang diukur di laboratorium dapat dilihat pada Tabel 4. Kandungan nitrat berkisar antara 0,0592 sampai dengan 4,6629 mg/L dengan rata-rata $0,67368 \mathrm{mg} / \mathrm{L}$. Kandungan $\mathrm{NO}_{3}$ pada perairan alami hampir tidak pernah lebih dari $0,1 \mathrm{mg} / \mathrm{L}$. Kandungan $\mathrm{NO}_{3}$ lebih dari $5 \mathrm{mg} / \mathrm{L}$ menggambarkan terjadinya pencemaran antropogenik yang berasal dari aktivitas manusia dan tinja hewan. Kandungan $\mathrm{NO}_{3}$ yang lebih dari 0,2 mg/L dapat mengakibatkan terjadinya eutrofikasi perairan yang selanjutnya menstimulir pertumbuhan alga dan tumbuhan air secara pesat. Tingginya kandungan $\mathrm{NO}_{3}$ diduga berasal dari kegiatan pertanian. Pada perairan yang menerima limpasan air dari daerah pertanian yang banyak mengandung pupuk, kandungan $\mathrm{NO}_{3}$ dapat mencapai 1,000 mg/L (Effendi, 2003).

Nitrit $\left(\mathrm{NO}_{2}\right)$ merupakan bentuk peralihan antara amonia dan nitrat (nitrifikasi) dan antara nitrat dan gas nitrogen (denitrifikasi). $\mathrm{NO}_{2}$ beracun terhadap ikan, karena mengoksidasikan besi (Fe) di dalam hemoglobin. Dalam bentuk ini kemampuan darah untuk mengikat oksigen terlarut sangat merosot (Poernomo, 1988). Pada udang yang darahnya mengandung tembaga ( $\mathrm{Cu}$ ) (hemocyanin) mungkin terjadi oksidasi $\mathrm{Cu}$ oleh $\mathrm{NO}_{2}$ dan memberikan akibat yang sama seperti pada ikan (Smith \& Russo, 1975 dalam Poernomo, 1988). Kandungan $\mathrm{NO}_{2}$ di kawasan pertambakan Kota Pekalongan berkisar antara 0,0008 dan $0,5666 \mathrm{mg} / \mathrm{L}$ dengan rata-rata $0,04310 \mathrm{mg} / \mathrm{L}$. Kandungan $\mathrm{NO}_{2}$ pada perairan relatif kecil karena segera dioksidasi menjadi nitrat. Perairan alami mengandung $\mathrm{NO}_{2}$ sekitar 0,001 mg/L dan sebaliknya tidak melebihi 0,06 $\mathrm{mg} / \mathrm{L}$ (Canadian Council of Resource and Environment Ministers, 1987 dalam Effendi, 2003). Di perairan, kandungan $\mathrm{NO}_{2}$ jarang melebihi 1 mg/L (Sawyer \& McCarty, 1978). Kandungan $\mathrm{NO}_{2}$ yang lebih dari 0,05 mg/L dapat bersifat toksik bagi organisme akuatik yang sangat sensitif (Moore, 1991). Oleh karena itu, kandungan $\mathrm{NO}_{2}$ air tambak belum berdampak dapat meracuni organisme air di tambak Kota Pekalongan. 
Tabel 4. Kualitas air tambak di Kota Pekalongan Provinsi Jawa Tengah yang diukur di laboratorium

Table 4. Water quality of bracksihwater ponds in Pekalongan City, Central Java Province measured ex situ

\begin{tabular}{lcccc}
\hline $\begin{array}{c}\text { Peubah } \\
\text { Variable }\end{array}$ & Minimum & $\begin{array}{c}\text { Maksimum } \\
\text { Maximum }\end{array}$ & $\begin{array}{c}\text { Rata-rata } \\
\text { Average }\end{array}$ & $\begin{array}{c}\text { Standardeviasi } \\
\text { Standard deviation }\end{array}$ \\
\hline Nitrat (Nitrate)(mg/L) & 0.0592 & 4.6629 & 0.67368 & 0.889944 \\
Nitrit (Nitrite) (mg/L) & 0.0008 & 0.5666 & 0.04310 & 0.122153 \\
Amonia (Ammonia)(mg/L) & 0.0030 & 0.3758 & 0.05437 & 0.071331 \\
Fosfat (Phosphate)(mg/L) & 0.0016 & 0.8483 & 0.10254 & 0.138692 \\
Besi (Iron) (mg/L) & 0.041 & 0.840 & 0.2172 & 0.21044 \\
\hline
\end{tabular}

Amonia dapat berada dalam bentuk molekul $\left(\mathrm{NH}_{3}\right)$ atau bentuk ion $\mathrm{NH}_{4}$, di mana $\mathrm{NH}_{3}$ lebih beracun daripada $\mathrm{NH}_{4}$ (Poernomo, 1988). $\mathrm{NH}_{3}$ dapat menembus bagian membran sel lebih cepat daripada $\mathrm{NH}_{4}$. Di tambak Kota Pekalongan, kandungan amonia berkisar antara 0,0030 dan $0,3758 \mathrm{mg} / \mathrm{L}$ dengan rata-rata $0,05437 \mathrm{mg} / \mathrm{L}$ (Tabel 4). Kandungan $\mathrm{NH}_{3}$ 0,05$0,20 \mathrm{mg} / \mathrm{L}$ sudah menghambat pertumbuhan organisme akuatik pada umumnya. Apabila kandungan $\mathrm{NH}_{3}$ lebih dari $0,2 \mathrm{mg} / \mathrm{L}$, perairan bersifat toksik bagi beberapa jenis ikan (Sawyer \& McCarty, 1978). Chanratchakool et al. (1995) menyatakan bahwa kandungan amonia yang diperkenankan untuk budidaya udang windu adalah kurang dari $0,1 \mathrm{mg} / \mathrm{L}$. Walaupun rata-rata kandungan amonia lebih kecil dari 0,1 $\mathrm{mg} / \mathrm{L}$, tetapi ada beberapa tambak yang memiliki kandungan air yang tergolong dapat mengganggu pertumbuhan organisme yang dibudidayakan di tambak Kota Pekalongan.

Kandungan fosfat pada perairan alami berkisar antara 0,005-0,020 mg/L, sedangkan pada air tanah biasanya berkisar $0,02 \mathrm{mg} / \mathrm{L}$ (UNESCO/WHO/UNEP, 1992 dalam Effendi, 2003). Kandungan $\mathrm{PO}_{4}$ jarang melebihi 0,1 $\mathrm{mg} / \mathrm{L}$, meskipun pada perairan eutrof. Kandungan $\mathrm{PO}_{4}$ pada perairan alami jarang melebihi $1 \mathrm{mg} / \mathrm{L}$ (Boyd, 1995). Berdasarkan kandungan fosfat, perairan diklasifikasikan menjadi tiga yaitu: perairan dengan kesuburan rendah, yang memiliki kandungan fosfat berkisar antara 0-0,02 mg/L; perairan dengan tingkat kesuburan sedang, yang memiliki kandungan fosfat 0,021-0,05 mg/L; dan perairan dengan tingkat kesuburan tinggi, yang memiliki kandungan fosfat 0,051-0,10 $\mathrm{mg} / \mathrm{L}$ (Yoshimura dalam Liaw, 1969).
Berdasarkan kriteria tersebut, maka tambak di Kota Pekalongan tergolong memiliki tingkat kesuburan tinggi.

Kandungan Fe air tambak Kota Pekalongan berkisar antara 0,041 dan $0,840 \mathrm{mg} / \mathrm{L}$ dengan rata-rata 0,2172 mg/L (Tabel 4). Kandungan Fe air ini tergolong rendah dan mendukung usaha budidaya perikanan. Kandungan Fe yang direkomendasikan oleh ANZECC dan ARMCANZ (2000) dalam Gosavi et al. (2004) adalah kurang dari 1,0 mg/L. Kandungan Fe 0,8-1,7 mg/L dapat merusak insang ikan salmon cokelat (Salmo trutta) (Peuranen et al., 1994 dalam Ritvo et al., 2004).

Kisaran pasang surut di kawasan pesisir Kota Semarang, Provinsi Jawa Tengah sekitar 1,0 m (Gambar 3). Kisaran pasang surut yang ideal untuk tambak budidaya udang adalah antara 1,5 dan 2,5 m. Walaupun tidak tergolong dalam kisaran pasut yang ideal, tetapi dengan elevasi tambak yang tepat maka tambak dapat dikeringkan dan diisi air secara gravitasi, tanpa pematang utama dibuat lebih lebar dan tinggi untuk menahan tekanan air waktu pasang tinggi dan surut rendah. Akan tetapi, dari hasil pengamatan selama penelitian menunjukkan adanya tambak yang memiliki ketinggian pematang yang rawan pada saat pasang tinggi atau pada saat terjadi rob (banjir pasang).

\section{Vegetasi}

Pada tahun 2006 Kelurahan Bandengan menjadi tempat pelaksanaan Program GERHAN (Gerakan Nasional Rehabilitasi Hutan dan Lahan) dari Departemen Kehutanan Republik Indonesia yakni telah dilakukan penanaman bakau (Rhizophora mucronata) sebanyak 234.000 bibit di lahan seluas 100 ha (90 ha di 


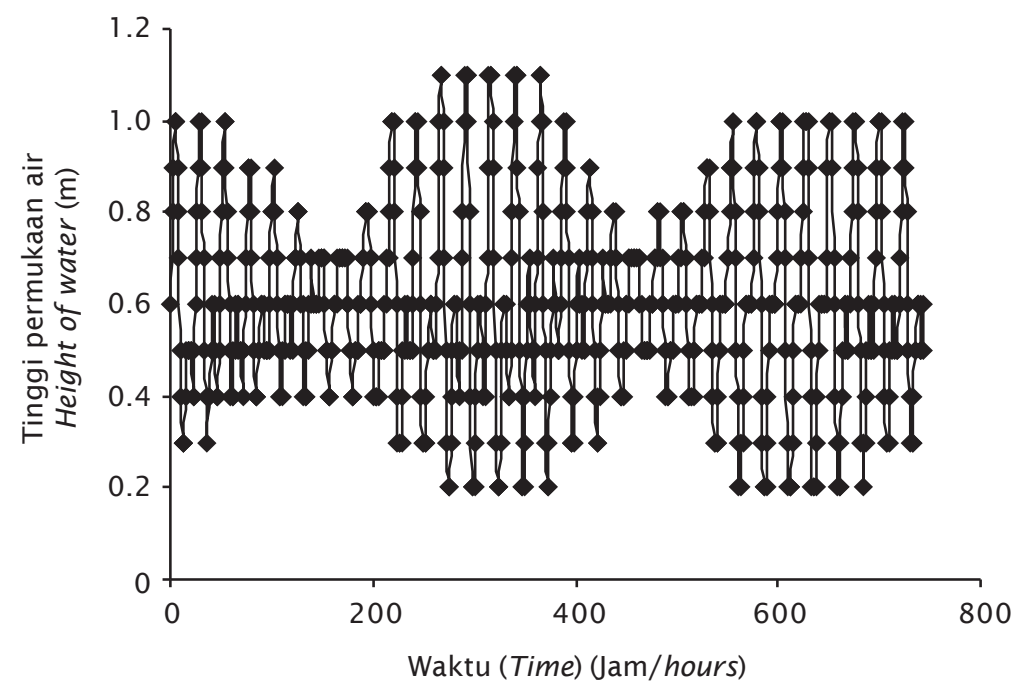

Gambar 3. Pasang surut di perairan laut Kota Semarang Provinsi Jawa Tengah

Figure 3. Tidal range in the coastal waters of Semarang City Central Java Province

tanam di pematang pertambakan dan saluran/ empang parit, 10 ha ditanam di lahan hamparan). Sampai saat ini pertumbuhannya cukup bagus dengan angka sintasan lebih dari 75\%. Di Kelurahan Kandang Panjang, komunitas mangrove juga baru terbangun melalui program GERHAN tahun 2006. Komunitas mangrove cukup jarang ditemui di Kelurahan Panjang Wetan. Komunitas mangrove cukup banyak ditemui di Kelurahan Krapyak Lor dengan dominasi jenis bakau (Rhizophora mucronata) dan nipah (Nypa fruticans). Di Kelurahan Degayu, pada tahun 2006 juga menjadi tempat pelaksanaan Program GERHAN seperti di Kelurahan Bandengan dan Kandang Panjang, namun tanaman yang dikembangkan adalah tanaman hutan kota seperti akasia (Acacia mangium), ketapang (Terminalia catappa) dan cemara laut (Casuarina equisetifolia) pada lahan seluas 25 ha.

\section{Iklim}

Salah satu faktor yang sangat berpengaruh terhadap budidaya tambak termasuk kualitas air tambak adalah iklim. Secara umum, iklim wilayah Kota Pekalongan yaitu beriklim tropis dengan suhu rata-rata berkisar antara $26^{\circ} \mathrm{C}-$ $28^{\circ} \mathrm{C}$ dan tertinggi $32^{\circ} \mathrm{C}$ dan kelembaban udara berkisar antara 64-86\%. Arah angin dipengaruhi oleh angin laut yang bertiup pada siang hari dari Utara ke Selatan, dan angin darat bertiup pada malam hari dari Selatan ke Utara. Di samping dipengaruhi oleh angin yang bertiup malam hari dari arah Barat Daya ke Tenggara dengan kecepatan rata-rata 2 knot/ jam. Pada bulan Desember-Maret bertiup agak kencang dengan kecepatan 3-4 knot/jam yang mengakibatkan gelombang di pantai menjadi besar.

Di antara berbagai unsur iklim, curah hujan adalah unsur iklim yang paling besar pengaruhnya terhadap budidaya tambak. Curah hujan bulanan yang rendah dijumpai pada Juni sampai Oktober, curah hujan yang lebih tinggi dijumpai pada bulan lainnya yaitu dari November sampai Mei (Gambar 4). Curah hujan rata-rata $2.300 \mathrm{~mm} /$ tahun di Kota Pekalongan. Curah hujan antara 2.000-3.000 $\mathrm{mm} /$ tahun dengan bulan kering 2-3 bulan cukup baik digunakan untuk tambak. Dengan demikian curah hujan di Kota Pekalongan tergolong baik untuk budidaya. Persiapan tambak adalah salah satu kegiatan yang harus dilakukan sebelum dilakukan penebaran. Pada saat persiapan tambak dilakukan pengeringan tambak dengan tujuan untuk memperbaiki sifat fisik tanah, meningkatkan mineralisasi bahan organik dan menghilangkan bahan-bahan beracun berupa hidrogen sulfida, amonia, dan metan. Karena itu diperlukan adanya bulan- 


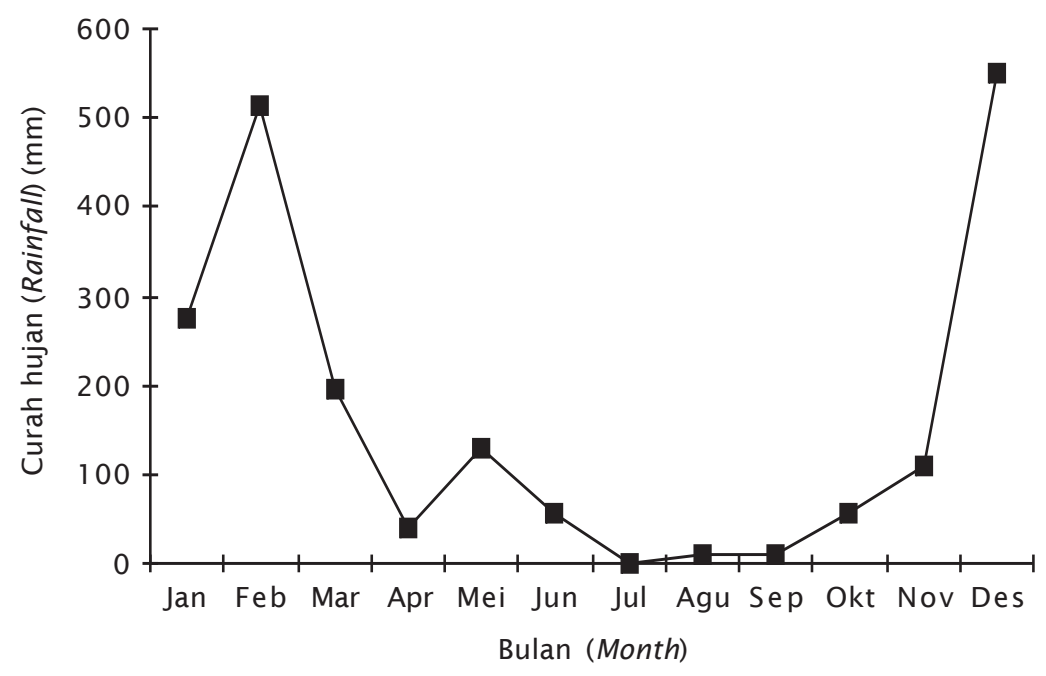

Gambar 4. Curah hujan bulanan di Kota Pekalongan Provinsi Jawa Tengah

Figure 4. Monthly rainfall variation in Pekalongan City Central Java Province

bulan kering tertentu pada setiap tahun. Bulan Juli sampai Oktober adalah saat yang tepat dalam melaksanakan persiapan tambak di Kota Pekalongan.

\section{Kesesuaian dan Pengelolaan Lahan}

Hasil analisis kesesuaian lahan menunjukkan bahwa dari luas tambak yang ada di Kota Pekalongan, yaitu 331,292 ha ternyata tidak ada tambak yang tergolong sangat sesuai (kelas S1), 191,856 ha tergolong cukup sesuai (kelas S2) dan 140,436 ha tergolong kurang sesuai (kelas S3) (Gambar 5). Hasil analisis kesesuaian lahan tersebut digolongkan kesesuaian lahan aktual sebab dinilai untuk kondisi saat ini berdasarkan data sifat biofisik tanah atau sumberdaya lahan sebelum lahan tersebut diberikan masukan-masukan yang diperlukan untuk mengatasi kendala atau faktor pembatas. Apabila usaha perbaikan dapat dilakukan, kelas kesesuaian lahan dapat naik satu tingkat pada golongan kesesuaian lahan potensial (Ritung et al., 2007).

Budidaya udang dengan teknologi tradisional sampai madya dapat dilakukan pada tambak yang tergolong cukup sesuai. Polikultur udang dan bandeng atau monokultur bandeng dapat dilakukan pada tambak yang tergolong kurang sesuai pada areal yang bukan tanah sulfat masam dan polikultur bandeng dan rumput laut dapat dilakukan pada tambak yang tergolong kurang sesuai pada areal tanah sulfat masam.

Faktor utama pembatas kesesuaian lahan untuk budidaya tambak di Kota Pekalongan adalah kandungan unsur atau senyawa penyebab kemasaman pada areal-areal tertentu di Kelurahan Bandengan, Panjang Wetan, Krapyak Lor, dan Degayu. Unsur atau senyawa penyebab kemasaman yang dimaksud adalah: pirit, bahan organik, besi, dan aluminium yang akhirnya dicerminkan dengan nilai $S_{\text {POS }}$ yang relatif tinggi. Pengelolaan lahan terutama tanah yang dapat dilakukan untuk menurunkan potensi kemasaman tanah adalah melalui remediasi baik berupa pengeringan dan pembilasan tanah maupun melalui pengapuran. Prinsip remediasi melalui pengeringan dan pembilasan tanah adalah pengeringan tanah untuk mengoksidasi pirit, perendaman untuk melarutkan dan menetralisir kemasaman atau menurunkan produksi kemasaman lanjut dan pembilasan untuk membuang hasil oksidasi dan meminimumkan cadangan unsurunsur beracun dalam tanah (Mustafa \& Rachmansyah, 2008). Bentuk lain remediasi berupa pengapuran dapat dilakukan untuk mengurangi unsur-unsur beracun dan unsurunsur penyebab kemasaman tanah yang masih tersisa dalam tanah.

Pupuk yang mengandung nitrogen seperti urea, menjadi faktor yang penting diperhatikan 


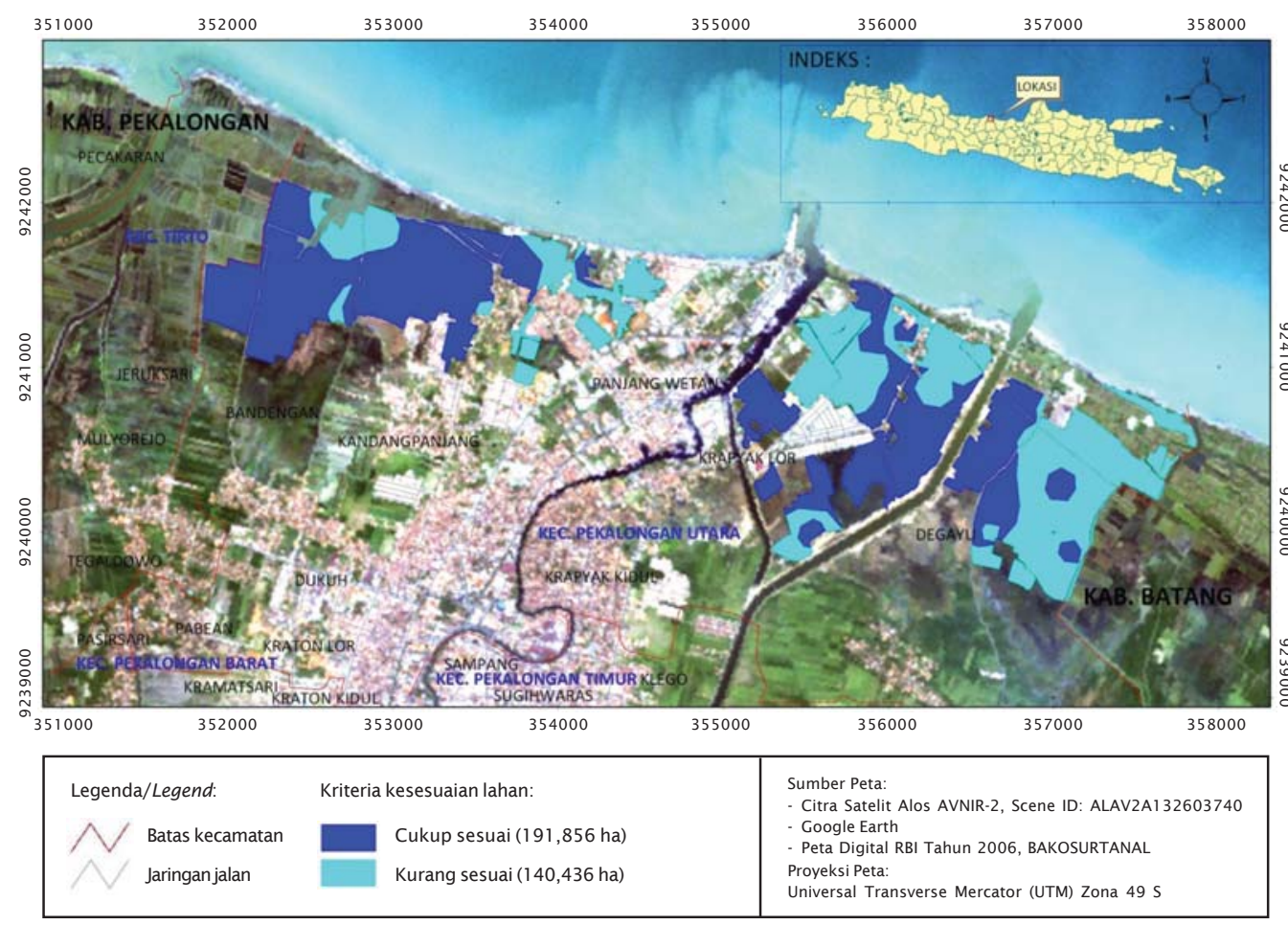

Gambar 5. Peta kesesuaian lahan aktual untuk budidaya tambak di Kota Pekalongan, Provinsi Jawa Tengah

Figure 5. Map of actual land suitability for brackishwater ponds in Pekalongan City Central Java Province

dalam budidaya tambak di Kota Pekalongan, terutama yang dikelola secara tradisional dan tradisional plus. Penggunaan pupuk yang mengandung nitrogen seperti urea diharapkan dapat menurunkan rasio $\mathrm{C}: \mathrm{N}$ tanah yang juga dapat mempercepat proses penguraian bahan organik.

Kandungan fosfat pada tanah tambak Kota Pekalongan tergolong sangat rendah (rata-rata kurang dari $43 \mathrm{mg} / \mathrm{L}$ ), baik pada kedalaman 0-0,2 m maupun 0,5-0,7 m. Ketersediaan fosfat lebih besar $60 \mathrm{mg} / \mathrm{L}$ dalam tanah tambak dapat digolongkan sebagai slight atau tergolong baik dengan faktor pembatas yang sangat mudah diatasi (Karthik et al., 2005). Dalam hal ini ada kemungkinan unsur fosfor dalam tanah terikat oleh Fe dan Al tanah sehingga menjadi tidak tersedia untuk pertumbuhan makanan alami di tambak. Pemberian pupuk yang mengandung fosfor seperti SP-36 juga disarankan diberikan pada saat persiapan tambak. Hal ini untuk mengantisipasi rendahnya kandungan fosfat tanah dan kemungkinan terikatnya fosfat oleh aluminium dan besi. Pupuk yang mengandung fosfor sebaiknya diberikan dalam bentuk larutan untuk mengurangi kemungkinan kontak langsung pupuk dengan tanah yang dapat berdampak pada pengikatan fosfat oleh aluminium dan besi, terutama pada tambak yang tergolong tinggi kandungan unsur atau senyawa penyebab kemasamannya seperti di areal-areal tertentu di Kelurahan Bandengan dan Krapyak Lor.

Pada tanah yang mengandung liat yang tinggi (>60\%), Boyd (1995) menetapkan kandungan bahan organik $<8 \%$ tergolong slight yaitu baik dan faktor pembatasnya mudah diatasi untuk budidaya tambak. Oleh karena itu, pada tambak yang kandungan liatnya lebih besar $60 \%$ dan kandungan bahan organiknya lebih rendah dari $8 \%$ disarankan untuk mengaplikasikan pupuk kandang sebagai sumber bahan organik yang juga dapat 
memperbaiki struktur tanah yang dapat menyebabkan pertumbuhan makanan alami terutama kelekap akan lebih baik.

Salinitas air yang relatif tinggi, sebagai akibat penelitian yang dilaksanakan pada musim kemarau, juga menjadi salah satu faktor pembatas kesesuaian lahan untuk budidaya tambak di Kota Pekalongan. Oleh karena itu, pemanfaatan sumber air tawar menjadi lebih penting serta usaha pergantian air yang lebih tinggi frekuensinya dapat dilakukan pada areal yang dekat dengan sumber air laut. Sumber air yang relatif keruh menuntut diperlukannya petak pengendapan sebelum air tersebut digunakan.

\section{KESIMPULAN DAN SARAN}

Tanah tambak di Kota Pekalongan tergolong tanah aluvial non-sulfat masam yang tidak memiliki potensi kemasaman tanah yang tinggi dan sebagian kecil tanah sulfat masam. Sumber air laut untuk tambak tergolong agak keruh dan salinitas air tambak cukup bervariasi sebagai akibat adanya sumber air tawar yang berasal dari Sungai Pekalongan dan sodetan. Vegetasi bakau adalah jenis vegetasi yang dominan di kawasan tambak sebab adanya Program GERHAN (Gerakan Nasional Rehabilitasi Hutan dan Lahan) di Kota Pekalongan. Curah hujan di Kota Pekalongan sebesar $2.300 \mathrm{~mm} /$ hujan di mana curah hujan yang rendah dijumpai pada bulan Juli sampai Oktober. Di kawasan pesisir Kota Pekalongan dijumpai tambak, sawah, sawah terintrusi dan pemukiman yang luasnya masing-masing 332,29; 372,53; 183,83; dan 619,73 ha. Dari luas tambak yang ada di Kota Pekalongan, yaitu 331,292 ha ternyata tidak ada tambak yang tergolong sangat sesuai (kelas S1), 191,856 ha tergolong cukup sesuai (kelas S2) dan 140,436 ha tergolong kurang sesuai (kelas S3). Pada areal yang mengandung unsur atau senyawa penyebab kemasaman yang tinggi disarankan untuk melakukan upaya perbaikan tanah terlebih dahulu berupa remediasi, pemberian pupuk yang mengandung nitrogen pada areal yang memiliki rasio $\mathrm{C}: \mathrm{N}$ tanah yang tinggi serta pemberian pupuk kandang pada tanah yang mengandung liat lebih besar $60 \%$ dan bahan organik kurang dari $8 \%$. Perlu adanya pemantauan kualitas air pada saat musim hujan untuk mendapatkan skenario lain dari kesesuaian lahan untuk tambak pada musim hujan.

\section{UCAPAN TERIMA KASIH}

Diucapkan terima kasih kepada Makmur, Rosiana Sabang, dan Ilham atas bantuannya dalam pengukuran dan pengambilan contoh tanah dan air di lapangan serta A. Sahrijannah, Siti Rohani, dan Kurnia atas bantuannya dalam analisis kualitas air di laboratorium dan juga Kamariah, Rahmiyah, dan Rismawati atas bantuan dalam analisis kualitas tanah di laboratorium. Diucapkan terima kasih kepada Bapak Kepala dan seluruh staf Dinas Pertanian, Peternakan dan Kelautan Kota Pekalongan atas segala bantuannya selama pelaksanaan penelitian ini.

\section{DAFTAR ACUAN}

Ahern, C.R. \& Blunden, B. 1998. Designing a soil sampling and analysis program. In: Ahern, C.R., Blunden, B. and Stone, Y. (eds.), Acid Sulfate Soils Laboratory Methods Guidelines. Acid Sulfate Soil Management Advisory Committee, Wollongbar, NSW, p. 2.1-2.6.

Ahern, C.R. \& McElnea, A.E. 2004. Calculated sulfur parameters. In: Acid Sulfate Soils Laboratory Methods Guidelines. Queensland Department of Natural Resources, Mines and Energy, Indooroopilly, Queensland, Australia, p. B11-1-B11-2.

Ahern, C.R., McElnea, A., \& Baker, D.E. 1998a. Peroxide oxidation combined acidity and sulfate. In: Ahern, C.R., Blunden, B. and Stone, Y. (eds.), Acid Sulfate Soils Laboratory Methods Guidelines. Acid Sulfate Soil Management Advisory Committee, Wollongbar, NSW, p. 4.1-4.17.

Ahern, C.R., McElnea, A., \& Baker, D.E. 1998b. Total oxidisable sulfur. In: Ahern, C.R., Blunden, B. and Stone, Y. (eds.), Acid Sulfate Soils Laboratory Methods Guidelines. Acid Sulfate Soil Management Advisory Committee, Wollongbar, NSW. p. 5.1-5.7.

Ahern, C.R. \& Rayment, G.E. 1998. Codes for acid sulfate soils analytical methods. In: Ahern, C.R., Blunden, B. and Stone, Y. (Eds.), Acid Sulfate Soils Laboratory Methods Guidelines. Acid Sulfate Soil Management Advisory Committee, Wollongbar, NSW, p. 3.1-3.5.

Anonymous. 1991. Mariculture of seaweeds. In: Shokita, S., Kakazu, K., Tomori, A. and Toma, T. (eds.), Aquaculture in Tropical Areas. Midori Shobo Co., Ltd., Tokyo, p. 31 95. 
APHA (American Public Health Association). 2005. Standard Methods for Examination of Water and Wastewater. APHA-AWWA-WEF, Washington, DC. 1,185 pp.

Blasco, F. 1984. Taxonomic considerations of the mangrove species. In: Snedaker, S.C. and Snedaker, J.G. (eds.), The Mangrove Ecosystems: Research Methods. UNESCO, Bungay, p. 81-113.

Boyd, C.E. 1995. Bottom Soil, Sediment, and Pond Aquaculture. Chapman and Hall, New York, $348 \mathrm{pp}$.

Boyd, C.E. 2008. Pond bottom soil analyses. Global Aquaculture Advocate September/ October, p. 91-92.

Bray, W.A., Lawrence, A.L., \& Leung-Trujill, J.R. 1994. The effect of salinity on growth and survival of Penaeus vannamei, with observations on the interaction of IHHN virus and salinity. Aquaculture, 122: 133-146.

Chanratchakool, P., Turnbull, J.F., Funge-Smith, S., \& Limsuwan, C. 1995. Health Management in Shrimp Ponds. Second edition. Aquatic Animal Health Research Institute, Department of Fisheries, Kasetsart University Campus, Bangkok, $111 \mathrm{pp}$.

Cintrõn, G. and Novelli, Y.S. 1984. Methods for studying mangrove structure. In: Snedaker, S.C. and Snedaker, J.G. (eds.), The Mangrove Ecosystems: Research Methods. UNESCO, Bungay, p. 91-113.

Effendi, H. 2003. Telaah Kualitas Air bagi Pengelolaan Sumber Daya dan Lingkungan Perairan. Penerbit Kanisius, Yogyakarta, $258 \mathrm{hlm}$.

Gosavi, K., Sammut, J., Gifford, S., \& Jankowski, J. 2004. Macroalgal biomonitors of trace metal contamination in acid sulfate soil aquaculture ponds. Science of the Total Environment, 324(1-3): 25-39.

Hossain, M.S. \& Das, N.G. 2010. GIS-based multicriteria evaluation to land suitability modelling for giant prawn (Macrobrachium rosenbergii) farming in Companigonj Upazila of Noakhali, Bangladesh. Computers and Electronics in Agriculture, 70(1): 172-186.

Hurtado-Ponce, A.Q. \& Umezaki, I. 1987. Growth rate studies of Gracilaria verrucosa (Gigartinales, Rhodophyta). Botanica Marina, 30: 223-226.

Ilyas, S., Cholik, F., Poernomo, A., Ismail, W., Arifudin, R., Daulay, T., Ismail, A., Koesoemadinata, S., Rabegnatar, I N.S.,
Soepriyadi, H., Suharto, H.H., Azwar, Z.I., \& Ekowardoyo, S. 1987. Petunjuk Teknis bagi Pengoperasian Unit Usaha Pembesaran Udang Windu. Pusat Penelitian dan Pengembangan Perikanan, Jakarta, $100 \mathrm{hlm}$.

Ismail, A., Poernomo, A., Sunyoto, P., Wedjatmiko, Dharmadi, \& Budiman, R.A.I. 1993. Pedoman Teknis Usaha Pembesaran Ikan Bandeng di Indonesia. Pusat Penelitian dan Pengembangan Perikanan, Jakarta, $73 \mathrm{hlm}$.

Jawatan Hidro-Oseanografi. 2009. Daftar Pawang Surut Kepulauan Indonesia tahun 2009. Jawatan Hidro-Oseanografi TNI-AL, Jakarta, $679 \mathrm{hlm}$.

Karthik, M., Suri, J., Saharan, N., \& Biradar, R.S. 2005. Brackish Water Aquaculture Site Selection in Palghar Taluk, Thane district of Maharashtra, India, Using the Techniques of Remote Sensing and Geographical Information System. Aquacultural Engineering, 32: 285-302.

Liaw, W.K. 1969. Chemical and biological studies of fishponds and reservoirs in Taiwan. Rep. Fish Culture Res., Fish. Series, Chin. Am. Joint Commission on Rural Reconstruction, 7: 1-43.

McElnea, A.E. \& Ahern, C.R. 2004a. KCl extractable $\mathrm{pH}\left(\mathrm{pH}_{\mathrm{KC}}\right)$ and titratable actual acidity (TAA). In: Acid Sulfate Soils Laboratory Methods Guidelines. Queensland Department of Natural Resources, Mines and Energy, Indooroopilly, Queensland, Australia, p. B2-1-B2-3.

McElnea, A.E. \& Ahern, C.R. 2004b. Peroxide $\mathrm{pH}\left(\mathrm{pH}_{\mathrm{ox}}\right)$, titartable peroxide acidity (TPA) and excess acid neutralising capacity $\left(\mathrm{ANC}_{\mathrm{E}}\right)$. In: Acid Sulfate Soils Laboratory Methods Guidelines. Queensland Department of Natural Resources, Mines and Energy, Indooroopilly, Queensland, Australia, p. B3-1-B3-7.

McElnea, A.E. \& Ahern, C.R. 2004c. Sulfur-peroxide oxidation method. In: Acid Sulfate Soils Laboratory Methods Guidelines. Queensland Department of Natural Resources, Mines and Energy, Indooroopilly, Queensland, Australia, p. B7-1-B7-2.

McElnea, A.E. \& Ahern ,C.R. 2004d. Sulfur $1 \mathrm{M}$ $\mathrm{KCl}$ extraction $\left(\mathrm{S}_{\mathrm{KCl}}\right)$. In: Acid Sulfate Soils Laboratory Methods Guidelines. Queensland Department of Natural Resources, Mines and Energy, Indooroopilly, Queensland, Australia, p. B8-1-B8-2.

Melville, M.D. 1993. Soil Laboratory Manual. 
School of Geography, The University of New South Wales, Sydney, 74 pp.

Menon, R.G. 1973. Soil and Water Analysis: A Laboratory Manual for the Analysis of Soil and Water. Proyek Survey O.K.T. Sumatera Selatan, Palembang, 190 pp.

Moore, J.W. 1991. Inorganic Contaminants of Surface Water. Springer-Verlag, New York, $334 \mathrm{pp}$.

Mustafa, A. \& Rachmansyah. 2008. Kebijakan dalam pemanfaatan tanah sulfat masam untuk budidaya tambak. Dalam: Sudradjat, A., Rusastra, I W. dan Budiharsono, S. (eds.), Analisis Kebijakan Pembangunan Perikanan Budidaya. Pusat Riset Perikanan Budidaya, Jakarta, hlm. 1-11.

Mustafa, A., Rachmansyah, \& Hanafi, A. 2007. Kelayakan Lahan untuk Budi Daya Perikanan Pesisir. Dalam: Susilo, D.S.I, Wiadnyana, N.N., Wijayanti, E., Basmal, J., Asnawi, Supangat, A., Hanggono, A., dan Insan, I. (eds.), Prosiding Simposium Nasional Hasil Riset Kelautan dan Perikanan Tahun 2007. Badan Riset Perikanan Budidaya, Jakarta, hlm. 141-157.

Parsons, T.R., Maita, Y., \& Lalli, C.M. 1989. A Manual of Chemical and Biological Methods for Seawater Analysis. Pergamon Press, Oxford, 173 pp.

Pérez, O.M., Ross, L.G., Telfer, T.C., \& del Campo Barquin, L.M. 2003. Water quality requirements for marine fish cage site selection in Tenerife (Canary Islands): predictive modelling and analysis using GIS. Aquaculture, 224: 51-68.

Poernomo, A. 1988. Pembuatan Tambak Udang di Indonesia. Seri Pengembangan No. 7. Balai Penelitian Perikanan Budidaya Pantai, Maros, $30 \mathrm{hlm}$.

Ponce-Palatox, J., Martinez-Palacios, C.A., \& Ross, L.G. 1997. The effect of salinity and temperature on the growth and survival rates of juvenile white shrimp, Penaeus vannamei, Boone, 1931. Aquaculture, 157: 107-115.

Rayes, M.L. 2007. Metode Inventarisasi Sumber Daya Lahan. Penerbit Andi, Yogyakarta, 298 hlm.

Ritung, S., Wahyunto, Agus, F., \& Hidayat, H. 2007. Panduan Evaluasi Kesesuaian Lahan dengan Contoh Peta Arahan Penggunaan Lahan Kabupaten Aceh Barat. Balai Penelitian Tanah dan World Agroforestry Centre (ICRAF), Bogor, Indonesia, $39 \mathrm{hlm}$.

Ritvo, G., Shitumbanuma, V., \& Dixon, J.B. 2004. Soil solution sulfide control by two ironoxide minerals in a submerged microcosm. Aquaculture, 239: 217-235.

Rossiter, D.G. 1996. A theoretical framework for land evaluation. Geoderma, 72: 165202.

Sawyer, C.N. \& McCarty, P.L. 1978. Chemistry for Environmental Engineering. Third edition. McGraw-Hill Book Company, New York, $532 \mathrm{pp}$.

Soil Survey Staff. 2001. Soil Taxonomy, a Basic System of Soil Classification for Making and Interpreting Soil Survey. United State Department of Agriculture, Washington, DC, $734 \mathrm{pp}$.

Sulaeman, Suparto, \& Eviati. 2005. Petunjuk Teknis Analisis Kimia Tanah, Tanaman, Air, dan Pupuk. Diedit oleh: Prasetyo, B.H., Santoso, D. dan Widowati, L.R. Balai Penelitian Tanah, Bogor, $136 \mathrm{hlm}$.

Swingle, H.S. 1968. Standardization of chemical analysis for waters and pond muds. FAO Fisheries Report, 44(4): 397-406.

Tsai, C.-K. 1989. Water quality management. In: Akiyama, D.M. (ed.), Proceedings of the Southeast Asia Shrimp Farm Management Workshop. American Soybean Association, Singapore, p. 56-63. 